\title{
Peningkatan Self-Efficacy Pada Siswa Melalui Konseling Cognitive Behavioral
}

\author{
Sopiyah $^{1)}$ \\ ${ }^{1)}$ Guru Bimbingan Konseling SMA N 2 Bandung \\ e-mail: sophie_udi@yahoo.com.au
}

\begin{abstract}
Abstrak. Penelitian ini bertujuan untuk mengetahui peningkatan self efficacy siswa melalui konseling cognitie behavioral. Pendekatan penelitian yang digunakan adalah penelitian kuantitatif. Metode yang digunakan dalam penelitian ini adalah metode eksperimen subject tunggal (single subject experiment). Subjek penelitian dipilih menggunakan purposive sampling. Data dihitung dengan menggunakan penghitungan Gain. Hasil penelitian menunjukkan bahwa Gain siswa pada level dengan scor 11, generalit y11, dan stenght 8 .Saran yang dapat diberikan adalah, karena temuan penelitian digunakan dalam seting lebih sempit seingga temuannya tidak mampu untuk melakukan kesimpulan secara umum, sehingga penelitian selanjutnya dapat menggunakan seting kelompok agar mampu melakukan generalisasi penelitian.
\end{abstract}

Kata Kunci: Peningkatan, Self Efficacy, konseling kognitive behavioral.

\section{Pendahuluan}

Siswa yang memiliki kecemasan tinggi pada pelajaran matematika cenderung memiliki self-efficacy yang rendah. Beberapa studi yang telah meneliti hubungan antara selfefficacy dengan kecemasan mengungkapkan individu yang mengalami kecemasan akan memperlihatkan ketakutan dan perilaku menghindar, yang seringkali mengganggu kinerja dalam kehidupan sehari - hari maupun dalam situasi akademis [2].

Bentuk perilaku menghindar yang sering muncul pada siswa yang mengalami kecemasan pada matematika antara lain keluar dari kelas, mengerjakan kegiatan lain, yang mengganggu proses belajar mengajar.

Hasil observasi dan konsultasi dengan guru matematika di kelas XI MIA (Matematika dan Ilmu Alam) SMAN 2 Bandung menunjukkan data sebagai berikut:

a. Siswa sering terlihat keluar kelas pada jam pelajaran matematika, mereka mengaku kalau dirinya sulit memahami pelajaran matematika, sehingga selalu ingin keluar ketika pelajaran tersebut.

b. Beberapa siswa berpendapat bahwa baik dengan belajar matematika ataupun tidak, mereka tetap merasa sulit memahami pelajaran matematika.

c. Siswa merasa tidak bersemangat mengikuti pelajaran matematika.

d. Berdasarkan analisis nilai ulangan harian dan partisipasi di kelas, perkembangan kemampuan matematika siswa kurang terlihat.

Hasil observasi dan konsultasi tersebut memiliki kesesuaian dengan temuan perilaku yang dikemukakan oleh Weinstein. Fakta lain menunjukkan siswa kelas XI program MIA banyak yang mampu berprestasi pada pelajaran matematika, bahkan mengikuti olimpiade tingkat regional hingga nasional. Siswa dengan karakteristik pada data di atas perlu diberikan intervensi self-efficacy-nya, sehingga mampu berprestasi pada pelajaran matematika.

Self-efficacy merupakan kepercayaan individu untuk mampu mencapai kesuksesan, sehingga akan memunculkan perilaku dan kebiasaan untuk mencapai hasil yang diinginkannya [2]. Self-efficacy membantu menentukan besar kecilnya usaha yang akan dikerahkan orang dalam suatu aktivitas, kegigihan ketika menghadapi rintangan, dan mengukur kemampuan diri saat situasi yang tidak cocok.

Menurut teori kognitif sosial Bandura, self-efficacy mempengaruhi pilihan orang dalam membuat dan menjalankan tindakan yang mereka kejar. Individu cenderung berkonsentrasi dalam tugas- tugas yang mereka rasakan mampu dan percaya dapat menyelesaikannya serta menghindari tugas-tugas yang tidak dapat mereka kerjakan. Mengubah self-efficacy berarti mengubah pola pikir, dan salah satu alternatif konseling yang dapat dilakukan adalah konseling kognitif-perilaku, atau yang biasa dikenal dengan istilah cognitive behavioral therapy (CBT).

Strategi cognitive behavioral therapy (CBT) berkorelasi dengan pengembangan self-efficacy dalam mengubah pikiran individu, perilaku, emosi, dan prestasi individu [3]. Intervensiperilaku kognitif di SMA akan membantu siswa menyadari tiga hal, yaitu (a) pola pikiryang mempengaruhi perilaku mereka; (b) cara mereka bisa mengendalikanpola piker; (c) cara mengaplikasikan langkah langkahintervensiuntuk mengubah perilaku [4]. Pengalaman pada sesi konseling memberikan kesempatan kepada siswa untuk tidak menghindari masalah melainkan memikirkan cara yang mampu dilakukannya untuk 
menyelesaikan masalah tersebut, sehingga muncul keyakinan pada diri akan kemampuannya menyelesaikan permasalahan.

Atas dasar temuan uraian tersebut, penting untuk dilakukan penelitian mengenai cognitive behavioral therapy (CBT) untuk meningkatkan self-efficacy siswa pada pelajaran matematika. Untuk selanjutnya dalam konteks penelitian ini cognitive behavioral therapy (CBT) akan diistilahkan sebagai konseling cognitive behavioral. Penelitian ini diharapkan menjadi alternatif bantuan untuk meningkatkan self-efficacy siswa yang rendah pada pelajaran matematika di SMAN 2 Bandung.

\section{Metode}

Metode yang digunakan dalam penelitian ini adalah metode eksperimen subjek tunggal (single subject experiment). Metode tersebut hanya melibatkan satu peserta saja, tetapi dapat juga mencakup beberapa subjek penelitian, berkisar 3 sampai 8 subjek. Setiap subjek berfungsi sebagai control bagi dirinya sendiri. Hal ini dapat dilihat dari kinerja subjek sebelum, selama, dan setelah diberi perlakuan (Horner, 2005, hlm.166). Metode eksperimen subjek tunggal dilakukan untuk memperoleh gambaran mengenai efektivitas intervensi yang dilaksanakan secara sengaja dan sistematis melalui konseling cognitive behavioral dalam meningkatkan selfefficacy siswa pada pelajaran matematika.

Populasi pada penelitian adalah seluruh siswa kelas XI MIA (Matematika dan Ilmu Alam) di SMA Negeri 2 Kota Bandung. Subjek penelitian dipilih menggunakan purposive sampling. Pemilihan siswa kelas XI didasarkan kepada pertimbangan Siswa kelas XI MIA adalah siswa yang baru saja naik kelas dan memiliki pengalaman baru dalam pelajaran matematika tingkat SMA, dan sedang mengalami transisi dari tingkatan pemula ke tingkatan ahli dalam matematika SMA [1]. Fase inilah yang menjadi pembentuk self-efficacy pada pelajaran matematika berdasarkan pengalaman kelas $\mathrm{X}$, siswa akan menilai kemampuan dan kepercayaannya pada pelajaran matematika di SMA.

\section{Hasil dan Pembahasan}

Konseli RW berpartisipasi selama tiga sesi konseling dan tiga sesi pengukuran. Grafik hasil pengukuran antara baseline dan intervensi disajikan sebagai berikut.

\begin{tabular}{|c|c|c|c|c|c|c|c|}
\hline \multirow{3}{*}{ 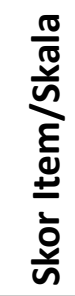 } & \multicolumn{4}{|c|}{ A (Baseline) } & \multicolumn{3}{|c|}{ B (Intervensi } \\
\hline & \multirow{2}{*}{$\begin{array}{r}40 \\
20 \\
0\end{array}$} & \multicolumn{3}{|c|}{ 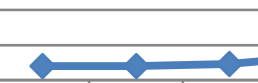 } & \multicolumn{3}{|c|}{ 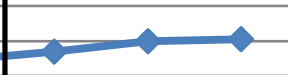 } \\
\hline & & $\begin{array}{c}\text { Sesi } \\
1\end{array}$ & $\begin{array}{c}\text { Sesi } \\
2\end{array}$ & $\begin{array}{c}\text { Sesi } \\
3\end{array}$ & $\begin{array}{c}\text { Sesi } \\
4\end{array}$ & $\begin{array}{c}\text { Sesi } \\
5\end{array}$ & $\begin{array}{c}\text { Sesi } \\
6\end{array}$ \\
\hline$\sim$ & ngukuran & 8 & 8 & 9 & 14 & 20 & 21 \\
\hline
\end{tabular}

Grafik 1. Kondiri self-efficacy RW pada Pelajaran Matematika Sebelum dan Setelah Intervensi

Grafik 1 menunjukkan terjadinya peningkatan selfefficacy RW pada pelajaran matematika setelah diberikan intervensi. Analisis terhadap grafik menunjukkan titik level skor terus meningkat, dan pada sesi pengukuran ke 5 danke 6 titik level grafik cenderun gstabil. Rata-rata skor selfefficacysecara keseluruhan pada baseline sebesar 8,3dan setelah diberikan intervensi meningkat menjadi 18,3 atau terjadi peningkatan sebesar 10 poin. Peningkatan skor tersebut mengindikasikan sejak diberikan intervensi, skor self-efficacy terus meningkat dan tidak kembali pada level baseline. Artinya konseling cognitive behavioral efektif untuk meningkatkan self-efficacy RW pada pelajaran matematika.

Self-efficacy merujuk pada kekuatan keyakinandiri individu untuk mampu melakukan sebuah tugas atau kegiatan, serta berpengaruh kepada motivasi dan prestasinya. Proses konseling RW dilakukan bertujuan untuk membangun dan merekonstruksi ulang kognitif RW yang merasa bahwa ia tertinggal dengan teman-temannya dalam pelajaran matematika, dan lambat berfikir dalam soal hitungan. Inilah yang menjadi faktor RW merasa tidak ada lagi motivasi untuk mempelajari pelajaran matematika. Sehingga keyakinan negative tersebut menjadikan persepsi dan daya kognitif RW lemah pada pelajaran matematika, sehingga memunculkan perilaku yang negative terhadap matematika.

Hasil penelitian menunjukan keyakinan dan persepsi negative padapelajaran matematika tersebut dapat di rekonstruksi kembali, yaitu dengan mengubah persepsi dan keyakinan dengan cara menyakinkan RW atas kemampuannya yang dikuatkandenganbanyak belajar dan latihan mengerjakan soal-soal matematika. Saat RW memiliki keyakinan untuk mengerjakan soal-soal matematika, maka keyakinanya tersebut akan menumbuhkan motivasi dan prestasinya.

\section{Simpulan dan Saran}

Intervensi konseling cognitive behavioral pada penelitian, terbukti efektif untuk meningkatkan selfeffacacy siswa pada pelajaran matematika. Siswa yang diberikan konseling cognitive behavioral mengalami peningkatan skor self-efficacy pada pelajaran matematika yang terlihat dari perbandingan skor rata-rata baseline dan skor intervensi yang digambarkan dalam bentuk grafik pada masing-masing subjek penelitian. Temuan hasil penelitian menunjukkan peningkatan skor self-effacacy pada pelajaran matematika. Konseli RW mengalami peningkatan sebesar 10 poin

\section{Referensi}

[1] Auliya, Risma Nurul. (2013). Pengaruh model pembelajaran kooperative tipe CRH( Course, Review, Hurray) terhadap kemampuan 
pemahaman matematis dan kecemasan siswa SMP. Universitas Pendidikan Indonesia. Repository.UPI.edu.

[2] Bandura, Albert. (1997). Self-efficacy: the exercise of control. New York: Freeman.

[3] Bandura, A. (1994). Self-efficacy. In V. S. Ramachaudran (Ed.), "Encyclopedia of human behavior”. (Vol. 4, pp. 71-81). New York: Academic Press. (Reprinted in H. Friedman [Ed.], Encyclopedia of mental health. San Diego: Academic Press, 1998).Beck AT. Thinking and depression: II theory and therapy. Arch Gen Psychiatry. 1964;10:561-71.

[4] Hall, R. J. \& Hughes, J. N. (1989). Cognitive behavioral approaches in the schools: A comprehensive handbook. New York: The Guilford press. 